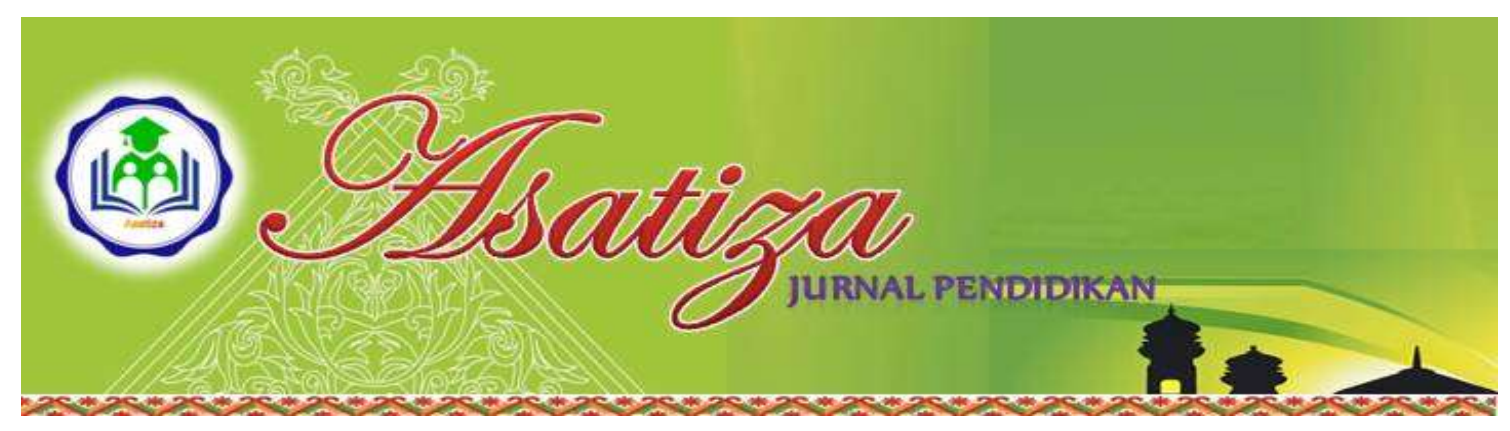

\title{
PERANAN PERPUSTAKAAN HARUN AL-RASYID DALAM MENINGKATKAN MOTIVASI BELAJAR MAHASISWA DI SEKOLAH TINGGI AGAMA ISLAM AULIAURRASYIDIN TEMBILAHAN \\ Siti Aysyah ${ }^{1}$
}

\author{
${ }^{1}$ Mahasiswi Prodi PAI STAI Auliurrasyidin Tembilahan, Indonesia
}

\begin{abstract}
Abstrak
Tujuan penelitian ini adalah untuk mengetahui Peranan Perpustakaan Harun Al-Rasyid dalam meningkatkan motivasi belajar Mahasiswa di sekolah Tinggi Agama Islam Auliaurrasyidin Tembilahan.

Jenis penelitian ini adalah deskriptip Kualitatif. Subjek penelitian yaitu pustakawan dan Mahasiswa PAI Tahun ajaran 2019-2020 semester III, V, VII berjumlah 368 Mahasiswa, dengan jumlah sampel 79 mahasiswa yang diambil dengan teknik Random Sampling. Tenik pengumpulan data yang digunakan adalah Angket, Wawancara dan Dokumentasi serta teknik analisis data diukur dengan persentase.

Hasil penelelitian dari Peranan Perpustakaan Harun Al-Rasyid dalam meningkatkan motivasi belajar mahasiswa di Sekolah Tinggi Agama Islam Auliaurrasyidin Tembilahan persentase $72,81 \%$ tergolong "BAIK" berdasarkan kategori interval persentase $61-80 \%$. Faktor-faktor yang mempengaruhinya adalah: Perpustakaan dijadikan sebagai sumber informasi, perpustakaan sebagai media yang berfungsi mengembangkan ilmu pengetahuan, untuk mencari tugas dan mendalami bahan atau bidang pengetahuan yang diberikan oleh dosen.
\end{abstract}

Kata Kunci: Peranan Perpustakaan, Meningkatkan, Motivasi Belajar.

\section{A. PENDAHULUAN}

\section{Latar Belakang}

Peranan adalah bagian dari tugas pokok harus dijalankan didalam perpustakaan. Oleh karena itu peranan yang harus dijalankan itu ikut menentu kan dan mempengaruhi tercapainya misi dan tujuan perpustakaan. ${ }^{1}$ Arti dari perpustakaan berasal dari kata pustaka, yang berarti buku. Setelah mendapat

${ }^{1}$ Sutarno Ns, Perpustakaan dan Masyarakat, (Jakarta: CV Sagung Seto, 2006), h. 68 awalan per dan akhiran an menjadi perpustakaan, yang berarti kitab, kitab perimbon, atau kumpulan buku-buku yang kemudian disebut koleksi bahan pustaka. $^{2}$

Pengertian perpustakaan selalu berkembang seiring dengan perkembang an ilmu pengetahuan dan teknologi informasi. Secara etimologi, perpustaka an berasal dari kata pustakadalam bahasa Kawi yang berarti buku, naskah, karya

${ }^{2}$ Sutarno NS, Manajemen Perpustakaan, (Jakarta: CV Sagung Seto, 2006), h . 11 
tulis. Perpustakaan berarti dibukukan, ditulis. Pustaka mendapat awalan per dan akhiran an, juga berarti tempat, atau kumpulan. Perpustakaan dalam bahasa Inggris adalah Library, yang berasal dari liber atau libri (latin) yang berarti kulit dari batang pohon dibawah luar, atau kitab, risalah. Veterum library adalah kitab-kitab klasik.

\section{Maksud dan Tujuan Perpustakaan}

Dalam Undang-Undang Republik Indonesia Nomor 43 Tahun 2007 tentang perpustakaan, Pasal 1 dalam undangundang ini yang dimaksud dengan:

a. Perpustaakaan adalah insitusi pengelola koleksi karya tulis, karya cetak, dan / karya rekam secara professional dengan sistem yang baku guna memenuhi kebutuhan pendidik an, penelitian, pelestarian, informasi, dan rekreasi para pemustaka.

b. Koleksi perpustakaan adalah semua informasi dalam bentuk karya tulis, karya cetak, dan/atau karya rekam dalam berbagai media yang mempunyai nilai pendidikan, yang dihimpun, diolah, dan dilayankan.

c. Koleksi nasional adalah semua karya tulis, karya cetak, dan/atau karya rekam dalam berbagai media yang diterbitkan ataupun tidak diterbitkan, baik yang berada didalam maupun diluar negri yang dimiliki oleh perpustakaan diwilayah Negara Kesatuan Republik Indonesia.

d. Naskah kuno adalah semua dokumen tertulis yang tidak dicetak atau tidk diperbanyak dengan cara lain, baik yang berada didalam negri maupun diluar negri yang berumur sekurangkurang 50 (lima puluh) tahun, dan yang mempunyai nilai penting bagi kebudayaan nasional, sejarah, dan ilmu pengetahuan.

e. Perpustakaan nasional adalah lembaga pemerintah non-departemen (LPND) yang melaksanakan tugas pemerintahan dalam bidsng perpustakaan yang berfungsi sebagai perpustakaan Pembina, perpustakaan rujukan, perpustakaan deposit, perpustakaan penelitian, perpustakaan pelestarian, dan pusat jejaring perpustakaan, serta berkedudukan di ibukota Negara.

f. Perpustakaan umum adalah perpustakaan yang diperuntukan bagi masyarakat luas sebagai sarana pembelajaran sepanjang hayat tanpa membedakan umur, jenis kelamin, suku, Ras, agama, dan status sosial ekonomi.

g. Perpustakaan khusus adalah perpustakaan yang diperuntukan secara terbatas bagi pemustaka dilingkungan lembaga pemerintah, lembaga masyarakat, lembaga pendidikan, keagamaan, rumah ibadah, atau organsasi lain.

h. Pustakawan adalah seorang yang memiliki kompetensi yang diperoleh melalui pendidikan dan/atau pelatihan kepustakawan serta mempunyai tugas dan tangung jawab untuk melaksana kan pengelolaan dan pelayanan perpustakaan.

i. Pemustaka adalah pengguna perpustakaan, yaitu perseorangan, kelompok orang, masyarakat, atau lembaga yang memanfaatkan fasilitas layanan perustakaan.

j. Bahan perpustakaan adalah semua hasil karya tulis, karya setak, dan/atau karya rekam. 
k. Masyarakat adalah setiap orang, kelompok orang, atau lembaga yang berdomisili pada suatu wilayah yang mempunyai perhatian, dan peranan dalam bidang perpustakaan.

1. Organisasi profesi pustakawan adalah perkumpulan yang berbadan hukum yang didirikan oleh pustakawan untuk mengembangkan profesionalitas kepustakawan.

m. Sumber daya perpustakaan adalah semua tenaga, sarana, dan prasarana, serta dana yang dimiliki dan/atau dikuasai oleh perpustakaan.

n. Menteri adalah menteri yang menangani urusan pemerintahan dalam bidang pendidikan nasional.

Dalam UU RI No. 43 Tahun 2007 tentang perpustakaan, Pasal 4:

"Perpustakaan bertujuan member kan layanan kepada pemustaka, meningkatkan kegemaran membaca, serta memperluas wawasan dan pengetahuan untuk mencerdaskan kehidupan bangsa". 3

\section{Peran perpustakaan}

Peranan sebuah perpustakaan adalah bagian dari tugas pokok yang harus dijalankan didalam perpustakaan. Oleh Karena itu peranan yang harus dijalankan itu ikut menentukan dan mempengaruhi tercapainya misi dan tujuan perpustakaan. Setiap perpustaka an yang dibangun akan mempunyai makna apabila dapat menjalankan peranannya dengan sebaik-baiknya. Peranan tersebut berhubungan dengan keberadan, tugas dan fungsi perpustakaan. Peranan yang dapat

${ }^{3}$ Undang-Undang Republik Indonesia Pasal 4 Nomor. 43 Tahun 2007 Tentang Perpustakaan.,www.bpkp.go.id. Di akses tanggal 8 januari 2019 jam 20.13 WIB dijalankan oleh perpustakaan antara lain adalah: Secara umum perpustakaan merupakan pusat sumber informasi, pendidikan, penelitian, preservasi dan pelestari khasanah budaya bangsa serta tempat rekreasi yang sehat, murah dan bermanfaat.

Perpustakaan merupakan media atau jembatan yang berfungsi menghubung kan antara sumber informasi dan ilmu pengetahuan yang terkandung didalam koleksi perpustakaan dengan para pemakainya. Perpustakaan mempunyai peranan sebagai sarana untuk menjalin dan mengembangkan komunikasi antara sesama pemakai, dan antara penyelenggara perpustakaan dengan masyarakat yang dilayani.

Perpustakaan dapat pula berperan sebagai lembaga untuk mengembangkan minat baca, kegemaran membaca, kebiasaan membaca, dan budaya baca, melalui penyediaan berbagai bahan bacaan yang sesuai dengan keinginan dan kebutuhan masyarakat. Oleh Karena itu apabila tidak ada perpustakaan, atau perpustakaan yang ada kurang berperan dengan baik, mungkin anggota masyarakat yang baru belajar membaca, atau sedang membiasakan diri membaca, dan yang membutuhkan sumber bacaan, dapat berkurang secara perlahan-lahan dan hilang semangatnya.

Perpustakaan dapat berperan aktif sebagai fasilitator, mediator, dan motivator bagi mereka yang ingin mencari, memanfaatkan, dan mengembangkan ilmu pengetahuan dan pengalamannya.

Perpustakaan merupakan agen perubahan, agen pembangunan, dan agen kebudayaan umat manusia. Sebab 
berbagai penemuan, sejarah, pemikiran, dan ilmu pengetahuan yang telah ditemukan pada masa yang lalu, yang direkam dalam bentuk tulisan atau berbentuk tertentu yang disimpan diperpustakaan. Koleksi tersebut dapat dipelajari, diteliti, dikaji, dan dikembangkan oleh generasi sekarang, dan kemudian dipergunakan sebagai landasan penuntun untuk merencanakan masa depan yang lebih baik.

Perpustakaan berperan sebagai lembaga pendidikan nonformal bagi anggota masyarakat dan pengunjung perpustakaan. Mereka dapat belajar secara mandiri (otodidak), melakukan penelitian, menggali, memanfaatkan dan mengembangkan sumber informasi dan ilmu pengetahuan.

Petugas perpustakaan dapat berperan sebagai pembimbing dan memberikan konsultasi kepada pemakai (users' education), dan pembinaan serta menanamkan pemahaman tentang pentingnya perpustakaan bagi orang banyak.

Perpustakaan berperan dalam menghimpun dan melestarikan koleksi bahan pustaka agar tetap dalam keadaan baik semua hasil karya umat manusia yang tak ternilai harganya.

Perpustakaan dapat berperan sebagai ukuran (barometer) atas kemajuan masyarakat dilihat dari intensitas kunjungan dan pemakaian perpustakaan. Sebab masyarakat yang sudah maju dapat ditandai dengan adanya perpustakaan yang sudah maju pula, sebaliknya masyarakat yang sedang berkembang biasanya belum memiliki perpustakaan yang memadai dan representatif.
Perpustakaan dapat berperan aktif dalam mencari atau menulusur, membina dan mengembangkan serta menyalurkan hobi atau kegemaran, minat, dan bakat yang dimiliki oleh perpustakaan. Kegiatan-kegiatan dimaksud antara lain melalui penelusuran bakat, minat, dan kemampuan yang dilakukan dengan mengadakan berbagai lomba, seperti melukis, baca puisi, mengarang, kuis dan lain-lain sehingga para peserta dapat menyalurkan, mengimplementasi kan dan mengembangkan bakat dan kreativitasnya dengan baik yang kelak dapat dijadikan salah satu pegangan dalam kehidupannya. ${ }^{4}$

Fungsi atau fungsi-fungsi perpustakaan adalah suatu tugas atau jabatan yang harus dilakukan didalam perpustakaan tersebut. Pada prinsipnya sebuah perpustakaan mempunyai tiga kegiatan utama yaitu (1) Menghimpun, (2) Memlihara, (3) Memberdayakan semua koleksi bahan pustaka.

Ada aspek manfaat perpustakaan bagi siswa/pengunjung yaitu:

a. Aspek komunikasi/informasi: Siswa dapat mengambil ide-ide dari berbagai sumber, bidang ilmu yang ditulis oleh para ahli bidangnya masing-masing, dan bahan-bahan tersebut tersedia atau tersimpan secara sistematis di perpustakaan, Menimbulkan keprcayaan pada diri sendiri dalam meyerapi informasi yang tersedia dan dapat memberikan pertimbangan atau memilih informasi atau ide-ide yang mana saja yang patut dimanfaatkan, Siswa mendapat kesempatan memakai informasi yang

\footnotetext{
${ }^{4}$ Sutarno NS, Op.Cit. h. 68-70.
} 
tersedia untuk mencapai tujuan-tujuan tertentu seperti pengetahuan tentang perubahan-perubahan ekonomi, politik, kondisi kehidupan masyarakat dan lain sebagainya.

b. Aspek pendidikan: Siswa mendapat kesempatan untuk mendidik diri sendiri berkesinambungan seumur hidup, Siswa dapat membangkitkan dan, mengembangkan minat akademis secara luas, mempertinggi kreatifitas dan kegiatan intelektual yang bebasMendorong kecepatan untuk memecahkan masalah yang timbul dan memberikan kemampun untuk memegang suatu jabatan, Mempertinggi sikap sosial dan menciptakan masyarakat yang demokratis.

c. Aspek kebudayaan: Meningkatkan mutu kehidupan, melalui bahan bacaan yang dibaca diperpustakaan, Meningkatkan minat terhadap keindahan dan kesenian, Mendorong tumbuhnya kreativitas seni dan kemerdekaan berbudaya, mengembangkan sifat-sifat hubungan manusia yang positif dan menunjang kehidupan antara kultur yang harmonis diantara suku bangsa dan antar bangsa, Sebagai lembaga untuk mengembangkan minat membaca, kegemaran membaca, melalui penyediaan berbagai bahan-bahan yang sesuai dengan keinginan dan kebutuhan.

d. Aspek rekreasi: Menggalakan kehidupan yang seimbang antara rohani dan jaminan, Meberikan kesempatan untuk mengembangkan minat rekreasi/hobi serta pemanfaat an waktu senggang, Menunjang penggunaan yang kreatif dari kegiatan hiburan yang positif, melalui bacaan yang tersedia diperpustakaan. ${ }^{5}$

\section{Motivasi Belajar}

Sumantri menyebutkan motivasi berasal dari kata motif yang diartikan sebagai "kekuatan yang terdapat dalam individu yang menyebabkan individu tersebut bertindak atau berbuat sesuatu yang mempunyai tujuan". 6 Selanjutnya, Sardiman menjelaskan motif dapat dikatakan sebagai penggerak dari dalam dan di dalam subjek untuk melakukan aktivitas-aktivitas tertentu demi mencapai suatu tujuan. ${ }^{7}$

Menurut Mc. Donald dalam Kompri mengatakan bahwa Motivasi adalah suatu perubahan energi di dalam probadi seseorang yang ditandai dengan timbulnya afektif (perasaan) dan reaksi fisik untuk mencapai tujuan. Perubahan energi tersebut dapat berbentuk suatu aktivitas nyata berupa kegiatan fisik. ${ }^{8}$

Lebih lanjut, Hamzah B. Uno dalam Sumantri menjelaskan "motivasi belajar adalah dorongan dan kekuatan dalam diri seseorang untuk melakukan tujuan tertentu yang ingin dicapainya".

Sementara itu, Sardiman dalam Sumantri menjelaskan motivasi belajar merupakan faktor psikis yang bersifat non-intelektual dan berperan dalam hal

${ }^{5}$ Agustinus Hermino, Op. Cit., h. 102-103

${ }^{6}$ Mohamad Syarif Sumantri, Strategi Pembelajaran, (Jakarta: Rajawali Pers, 2015), h. 1

${ }^{7}$ Sardiman A.M, Interaksi dan Motivasi Belajar Mengajar, (Jakarta: Rajawali Pers, 2016), h. 73

${ }^{8}$ Kompri, Motivasi Pembelajaran Perspektif Guru dan Siswa, (Bandung: Remaja Rosdakarya, 2015), h. 229. 
penumbuh gairah, merasa senang, dan semangat untuk belajar. ${ }^{9}$

\section{Fungsi Motivasi Belajar}

Motivasi mempunyai peranan yang strategis dalam aktivitas belajar seseorang. Menurut Wahab, fungsi motivasi dalam belajar yaitu:

a. Motivasi sebagai pendorong perbuatan. Maksudnya Pada mulanya siswa tidak ada hasrat untuk belajar, tetapi karena ada sesuatu yang dicari muncullah minatnya untuk belajar. Sesuatu yang akan dicari itu dalam rangka untuk memuaskan rasa ingin tahunya dari sesuatu yang akan dipelajari. Sesuatu yang belum diketahui tersebut akhirya mendorong siswa untuk belajar dalam rangka mencari tahu. Sikap itulah yang mendasari dan mendorong ke arah kegiatan belajar.

b. Motivasi sebagai penggerak perbuatan. Dorongan psikologis yang melahirkan sikap siswa untuk melakukan sejumlah perbuatan.

c. Motivasi sebagai pengarah perbuatan. Peserta didik yang mempunyai motivasi dapat menyeleksi mana perbuatan yang harus dilakukan dan mana perbuatan yang diabaikan. Sesuatu yang akan dicari siswa merupakan tujuan belajar yang akan dicapainya. Tujuan belajar itulah sebagai pengarah yang memberikan motivasi kepada siswa untuk belajar. $^{10}$

Secara umum dapat dikatakan bahwa tujuan motivasi adalah untuk menggerakkan atau menggugah

${ }^{9}$ Mohamad Syarif Sumantri, Op. Cit, h. 378.

${ }^{10}$ Rohmalina Wahab, Psikologi Belajar, (Jakarta: Rajawali Pers, 2016), h. 131 seseorang agar timbul keinginan dan kemauannya untuk melakkan sesuatu sehingga dapat memperoleh hasil atau mencapai tujuan tertentu. Bagi seorang guru, tujuan motivasi adalah untuk menggerakkan atau memacu para siswanya agar timbul keinginan dan kemauannya untuk meningktakan prestasi belajarnya sehingga tercapai tujuan pendidikan sesuai dengan yang diharapkan dan ditetapkan didalam kurikulum sekolah. Oleh karena itu, setiap orang yang akan memberikan motivasi harus mengenal dan memahami benar-benar latar belakang kehidupan, kebutuhan, dan kepribadian orang yang akan dimotivasi. ${ }^{11}$

\section{B. METODOLOGI}

Jenis penelitian yang penulis gunakan adalah jenis penelitian deskriptif kualitatif subjek dalam penelitian ini adalah mahasiswa semester III, V, VII Tahun ajaran 2019/2020 Sekolah Tinggi Agama Islam Auliaurrasyidin Tembilahan Objek penelitian ini adalah mengenai Peranan Perpustakaan Harun Al-Rasyid Dalam Meningkatkan Motivasi Belajar Mahasiswa Di Sekolah Tingi Agama Islam Auliaurrasyidin Tembilahan Populasi dalam penelitian ini adalah seluruh mahasiswa PAI terhitung dari semester III, V, VII Tahun ajaran 2019/2020 di Sekolah Tinggi Agama Islam Auliaurrasyidin Tembilahan jumlah sampel dari populasi $10 \%$ yaitu 79 mahasiswa, maka langkah selanjutnya adalah mengalokasikan atau menyebar kan satuan-satuan sampel ini kepada

\footnotetext{
${ }^{11}$ Ngalim Purwanto, Op. Cit, h. 73-74
} 
setiap kelas dengan menggunakan pengambilan sampel secara Proportionate stratified random sampling.

Teknik pengumpulan data yang penulis gunakan untuk mengumpulkan data penelitian yaitu: angket, wawancara dan dokumentasi. Teknik analisis data diukur dengan menggunakan persentase

\section{PEMBAHASAN}

Dari rekapitulasi data dapat diketahui jawaban masing-masing opsional adalah sebagai berikut:

Opsional A : Selalu : :243

Opsional B : Sering $\quad: 260$

Opsional C : Kadang-kadang : 262

Opsional D : Tidak Pernah : 25

Sehingga nilai $N=243+260+262+$ $25=790$

Selanjutnya masing-masing jawaban di berikan skor alternatif jawaban Selalu diberi skor 4, alternatif jawaban sering diberi skor 3, alternatif jawaban kadangkadang diberi skor 2 alternatif jawaban tidak pernah diberi skor 1 .

Dari penskoran didapat hasil sebagai berikut:

\begin{tabular}{|c|c|}
\hline Opsional A & $=243 \times 4$ \\
\hline Opsional B & $=260 \times 3$ \\
\hline Opsional C & $=262 \times 2$ \\
\hline Opsional D & $=25 \times 1$ \\
\hline
\end{tabular}

Sehingga nilai $\mathrm{F}=972+780+524+$ $25=2301$

Dengan demikian diketahui bahwa $\mathrm{F}=$ 2301, Sedangkan:

$\mathrm{N}=$ Jumlah Populasi $\mathrm{X}$ Jumlah Pertanyaan pada angket $\mathrm{X}$ Skor Tertinggi

$79 \times 10 \times 4=3160$

Hasil penelitian dari Peranan Perpustakaan Harun Al-Rasyid dalam
Meningkatkan Motivasi Belajar Mahasiswa Sekolah Tinggi Agama Islam Auliaurrasyidin Tembilahan, digunakan rumus: $P=\frac{F}{N} X \quad 100 \% \frac{2301}{3160} X 100 \%=$ $\mathbf{7 2 , 8 1 \%}$

Peneliti melakukan wawancara terhadap kepala perpustakaan Harun AlRasyid, penjaga perpustakaan berjumlah 2 orang, dan 2 orang mahasiswa STAI Auliaurrasyidin untuk mendukung data angket. Data hasil wawancara tersebut dijadikan secara berurutan dibawah ini:

1. Apa yang menjadi sasaran dan tujuan dari perpustakaan Harun Al-Rasyid?

"Menurut saya, tujuan perpustakan Harun Al-Rasyid adalah untuk mendukung, mem perlancar serta mempertinggi kualitas pelaksanaan program kegiatan Tri Dharma Perguruan Tinngi di STAI Auliaurrasyidin melalui pelayanan informasi yang meliputi aspek: pengumpulan informasi, pengolahan informasi, penyajian informasi, pelestarian informasi, penyebarluasan infor masi. Sasaran nya yaitu terutama mahasiswa kemudian dosen beserta staf-staf STAI Auliaurrasyidin Tembilahan". ${ }^{12}$

"Menurut saya, Tri Dharma Perguruan Tinggi, untuk menunjang penelitian, ada 3 Tri Dharma yaitu, pengajaran, penelitian dan pengabdian kepada masyarakat. Kemudian buku bisa dijadikan sebagai refrensi mahasiswa baik makalah maupun skripsi". ${ }^{13}$

${ }^{12}$ Abdul Hamid S. Si, Wawancara dengan kepala Perpustakaan Harun Al-Rasyid STAI Auliaurrasyidin Tembilahan pada hari Rabu Tanggal 10 Oktober 2019 Diruang Kepala Perpustakaan.

${ }^{13}$ Paidi, S. IP Wawancara dengan Pustakawan Perpustakaan Harun Al-Rasyid STAI Auliaurrasyidin Tembilahan Pada Hari 
"Menurut saya, untuk membantu sivitas akademika seperti untuk penelitian, bisa mencari buku-buku disini. Tujuan mempermudah informasi atau menyelesaikan permasalahan salah satunya tugas dari dosen". ${ }^{14}$

2. Apa yang menjadi kebijakan dalam perpustakaan Harun Al-Rasyid?

"Menurut saya, kebijakan didalam perpustakaan yang menjadi anggota perpustakaan tidak dipungut biaya untuk membuat kartu perpustakaan, semua gratis". ${ }^{15}$

"Menurut saya, berusaha untuk melayani mahasiswa atau dosen secara umum akademik STAI Auliaurrasyidin untuk dapat mencari apa yang mereka butuhkan, kemudahan dalam mencari bukubuku". ${ }^{16}$

"Menurut saya, kebijakan yang menjadi anggota itu mahasiswa, karyawan maupun dosen. Jadwal buka nya perpustakaan yaitu dalam satu minggu itu 6 hari kecuali tanggal merah itu libur.Pereturan lebih khusus
Rabu tanggal 09 Oktober 2019 di Ruang Perpustakaan.

${ }^{14}$ Revita Maulani S. IP, Wawancara dengan Pustakawan Perpustakaan Harun Al-Rasyid STAI Auliaurrasyidin Tembilahan Pada Hari Rabu tanggal 09 Oktober 2019 di Ruang Perpustakaan.

${ }^{15}$ Abdul Hamid S. Si, Wawancara dengan kepala Perpustakaan Harun Al-Rasyid STAI Auliaurrasyidin Tembilahan pada hari Rabu Tanggal 10 Oktober 2019 Diruang Kepala Perpustakaan.

${ }^{16}$ Paidi, S. IP Wawancara dengan Pustakawan Perpustakaan Harun Al-Rasyid STAI Auliaurrasyidin Tembilahan Pada Hari Rabu tanggal 09 Oktober 2019 di Ruang Perpustakaan. itu sudah tertera didalam buku koleksi". ${ }^{17}$

3. Apa wewenang dan tanggung jawab setiap pegawai perpustakaan?

"Menurut saya, wewenang dan tanggung jawab setiap pegawai itu meliputi: yang pertama yaitu menyediakan dan megolah bahan kepustakaan. Ke dua, memberikan layanan dan pendayagunaan bahan pustaka, ke tiga, melakukan pelayanan referensi, ke empat, memelihara bahan kepustakaan, terakhir melakukan urusan tata usaha kepustakaan". ${ }^{18}$

"Menurut saya, melaksanakan tugas dari kepala perpustakaan, mengola input data sendiri, perbaikan koleksi buku-buku". ${ }^{19}$

"Menurut saya, ada buku masuk di input, kemudian input data mahasiswa baru, ada peminjaman kemudian pengembalian. Sirkulasi diperpustakaan itu kita yang menangani sendiri disini. Kalau ada yang melanggar peraturan itu diberikan sanksi, untuk perawatan buku-buku itu dibersikan dan dirapikan". ${ }^{20}$

${ }^{17}$ Revita Maulani, S. IP Wawancara dengan Pustakawan Perpustakaan Harun Al-Rasyid STAI Auliaurrasyidin Tembilahan Pada Hari Rabu tanggal 09 Oktober 2019 di Ruang Perpustakaan.

${ }^{18}$ Abdul Hamid S. Si, Wawancara dengan kepala Perpustakaan Harun Al-Rasyid STAI Auliaurrasyidin Tembilahan pada hari Rabu Tanggal 10 Oktober 2019 Diruang Kepala Perpustakaan.

${ }^{19}$ Paidi, S. IP Wawancara dengan Pustakawan Perpustakaan Harun Al-Rasyid STAI Auliaurrasyidin Tembilahan Pada Hari Rabu tanggal 09 Oktober 2019 di Ruang Perpustakaan.

${ }^{20}$ Revita Maulani, S. IP Wawancara dengan Pustakawan Perpustakaan Harun Al-Rasyid STAI Auliaurrasyidin Tembilahan Pada Hari 
4. Bagaimana kegiatan kerja dalam perpustakaan dilakukan?

"Menurut saya, kegiatan kerja di dalam perpustakaan yaitu melayani mahasiswa, maupun dosen dalam peminjaman buku-buku baik itu bagi mahasiswa untuk mencari tugas yang diberikan oleh dosen atau pun untuk penelitian skripsi. Jadi tugas setiap pustakawan itu bisa meinput data peminjaman, pengembalian, kemudian menyusun koleksi-koleksi buku yang ada diperpustakaan tersebut". ${ }^{21}$

"Menurut saya, pengajuan buku-buku oleh kepala perpustakaan yaitu bapak Abdul Hamid S. Si, itu terjadi saat mahasiswa baru mulai masuk karena disini ada 4 jurusan diajukan setalah buku diajukan oleh pimpinan, kemudian buku dibeli dimasukan keperpustakaan kemudian dipin jamkan kepada mahasiswa". ${ }^{22}$

"Menurut saya, kegiatan kerja sirkulasi, dimana ada kartu perpustakaan mahasiswa yang hilang atau ada mahasiswa baru kita input data mahasiswa, kemudian ada buku baru kita input data buku baru, ada peminjaman atau pengembalian kita proses dikomputer". 23

Rabu tanggal 09 Oktober 2019 di Ruang Perpustakaan.

${ }^{21}$ Abdul Hamid, S.Si, Wawancara dengan kepala Perpustakaan Harun Al-Rasyid STAI Auliaurrasyidin Tembilahan pada hari Rabu Tanggal 10 Oktober 2019 Diruang Kepala Perpustakaan.

${ }^{22}$ Paidi, S.IP Wawancara dengan Pustakawan Perpustakaan Harun Al-Rasyid STAI Auliaurrasyidin Tembilahan Pada Hari Rabu tanggal 09 Oktober 2019 di Ruang Perpustakaan.

${ }^{23}$ Revita Maulani, S.IP Wawancara dengan Pustakawan Perpustakaan Harun Al-Rasyid STAI Auliaurrasyidin Tembilahan Pada Hari
5. Apa kendala dalam mengelola dan mengolah perpustakaan?

"Menurut saya, kendala yaitu sumber daya manusia masih kurangnya pegawai, Karena kurangnya sumber daya manusia tadi maka pekerjaan menjadi terhambat. Kemudian permasalahan teknis masih kecilnya gedung yang digunakan untuk jumlah koleksi-koleksi buku yang ada diperpustakaan ini". ${ }^{24}$

"Menurut saya, kurangnya sumber daya manusia, kerja tidak bisa cepat untuk informasi baru masuk itu kita harus update seharusnya bisa cepat dilayani tetapi tidak bisa karena terkendala tenaga. Terkendala waktu yang seharusnya bisa cepat itu bisa menjadi lama". ${ }^{25}$

6. Apa saja sumber daya yang tersedia didalam perpustakaan?

"Menurut saya, sumber daya yang tersedia di dalam perpustakaan meliputi: Pustaka wan berjumlah 2 orang, buku koleksi, komputer + Wifi, Rak-rak buku". ${ }^{26}$

7. Apakah Perpustakaan dapat dijadikan sebagai media atau jembatan yang

Rabu tanggal 09 Oktober 2019 di Ruang Perpustakaan.

${ }^{24}$ Paidi, S.IP Wawancara dengan Pustakawan Perpustakaan Harun Al-Rasyid STAI Auliaurrasyidin Tembilahan Pada Hari Rabu tanggal 09 Oktober 2019 di Ruang Perpustakaan

${ }^{25}$ Revita Maulani, S.IP Wawancara dengan Pustakawan Perpustakaan Harun Al-Rasyid STAI Auliaurrasyidin Tembilahan Pada Hari Rabu tanggal 09 Oktober 2019 di Ruang Perpustakaan.

${ }^{26}$ Abdul Hamid, S.Si, Wawancara dengan kepala Perpustakaan Harun Al-Rasyid STAI Auliaurrasyidin Tembilahan pada hari Rabu Tanggal 10 Oktober 2019 Diruang Kepala Perpustakaan. 
berfungsi mengembangkan ilmu pengetahuan?

"Menurut saya, tentu sudah jelas sekali karena perpustakaan jendela dunia dimana disini tempatnya bukubuku ilmu pengetahuan tentunya perpustaka an ini merupakan suatu yang bisa dijadikan untuk mengembangkan ilmu pengetahuan khususnya untuk mahasiswa/I STAI Auliaurrasyidin tembialhan". ${ }^{27}$

"Menurut saya, bisa karena saya juga merasakan bahwa perpustakaan ini bisa bermanfaat, apa lagi untuk mahasiswa semester akhir dan untuk mengembangkan ilmu pengetahuan karena banyak sumber ilmu pengetahuan didalamnya". ${ }^{28}$

8. Apakah Perpustakaan dapat dijadikan sebagai sarana untuk menjalin dan mengembangkan komunikasi antar mahasiswa dan dosen?

"Menurut saya, iya jelas karena diperpustakaan bukan tempatnya buku saja karena mahasiswa mencari tugas dari dosen itu diperpustakaan jadi disini tempat sarana untuk mempertemukan mahasiswa maupun dosen". 29

"Menurut saya, bisa saja terjadi karena yang sering terjadi itu

${ }^{27}$ Arfiani Sulaiman, Wawancara Dengan Salah Satu Mahasiswi Semeseter IX STAI Auliaurrasyidin Tembilahan Pada Hari Rabu Tanggal 09 Oktober 2019 Di Ruang Perpustakaan.

${ }^{28}$ Nida Agustina, Wawancara Dengan Salah

Satu Mahasiswi Semeseter IX STAI Auliaurrasyidin Tembilahan Pada Hari Rabu Tanggal 09 Oktober 2019 Di Ruang Perpustakaan.

${ }^{29}$ Arfiani Sulaiman, Wawancara Dengan Salah Satu Mahasiswi Semeseter IX STAI Auliaurrasyidin Tembilahan Pada Hari Rabu Tanggal 09 Oktober 2019 Di Ruang Perpustakaan. interaksi antar mahasiwa dan mahasiswa jarang sekali antar mahasiswa dan dosen". 30

9. Apakah Perpustakaan dapat dijadikan sebagai lembaga untuk mengembangkan minat literasi terhadap ilmu pengetahuan?

"Menurut saya, bisa jadi tetapi tergantung pengelolanya kalau pengelolanya tidak bersifat aktif dalam merasakan literasi dalam mengembangkan lembaganya maka itu tidak akan berjalan. Apa lagi minat baca sekarang masih minim sekali, agar suatu lembaga mengadakan literasi agar minat baca mahasiswa itu meningkat". ${ }^{31}$

"Menurut saya, bisa walaupun peminatnya itu tidak banyak karena masih kurang sekali minat baca mahasiswa, mengunjungi perpustaka an itu lebih untuk tugas". 32

10. Apakah Perpustakaan dapat diajadikan sebagai dalam mencari tugas dan mendalami bahan atau bidang pengetahuan yang diberikan oleh dosen?

"Menurut saya, jelas sekali salah satu tujuannya keperpustkaan yaitu

\footnotetext{
${ }^{30}$ Nida Agustina, Wawancara Dengan Salah Satu Mahasiswi Semeseter IX STAI Auliaurrasyidin Tembilahan Pada Hari Rabu Tanggal 09 Oktober 2019 Di Ruang Perpustakaan.

${ }^{31}$ Arfiani Sulaiman, Wawancara Dengan Salah Satu Mahasiswi Semeseter IX STAI Auliaurrasyidin Tembilahan Pada Hari Rabu Tanggal 09 Oktober 2019 Di Ruang Perpustakaan.

${ }^{32}$ Nida Agustina, Wawancara Dengan Salah Satu Mahasiswi Semeseter IX STAI Auliaurrasyidin Tembilahan Pada Hari Rabu Tanggal 09 Oktober 2019 Di Ruang Perpustakaan.
} 
mencari tugas, salah satunya yaitu makalah maupun penelitian skripsi". ${ }^{33}$

"Menurut saya, tentu saja dan harus dilakukan karena tujuan utama mahasiswa setelah mendapatkan tugas dari dosen itu biasanya langsung ke perpustakaan, biasanya itu terjadi diawal semester". ${ }^{34}$

11. Apakah Perpustakaan dapat dijadikan untuk Mengembangkan kecakapan berbahasa?

"Menurut saya, bisa asalkan mahasiswa itu aktif dalam membaca jadi bukan sekedar untuk mencari tugas tetapi bisa untuk menambah kecakapan didalam berbahasa tentu kalau kita baca buku itu menambah pembendaharaan bahasa kita". ${ }^{35}$

"Menurut saya, bagi mahasiswa yang benar-benar membaca itu harus bisa menambahkan kecakapan berbahasa nya". 36

\section{KESIMPULAN}

Peranan perpustakaan Harun AlRasyid Dalam Meningkatkan Motivasi Belajar Mahasiswa Di Sekolah Tinggi

${ }^{33}$ Arfiani Sulaiman, Wawancara Dengan Salah Satu Mahasiswi Semeseter IX STAI Auliaurrasyidin Tembilahan Pada Hari Rabu Tanggal 09 Oktober 2019 Di Ruang Perpustakaan.

${ }^{34}$ Nida Agustina, Wawancara Dengan Salah

Satu Mahasiswi Semeseter IX STAI Auliaurrasyidin Tembilahan Pada Hari Rabu Tanggal 09 Oktober 2019 Di Ruang Perpustakaan.

${ }^{35}$ Arfiani Sulaiman, Wawancara Dengan Salah Satu Mahasiswi Semeseter IX STAI Auliaurrasyidin Tembilahan Pada Hari Rabu Tanggal 09 Oktober 2019 Di Ruang Perpustakaan.

${ }^{36}$ Nida Agustina, Wawancara Dengan Salah Satu Mahasiswi Semeseter IX STAI Auliaurrasyidin Tembilahan Pada Hari Rabu Tanggal 09 Oktober 2019 Di Ruang Perpustakaan.
Auliaurrasyidin Tembilahan, dengan hasil angket diperoleh 72,81\% dikategorikan "BAIK"

Faktor-faktor yang mempengaruhi baiknya Peranan Perpustakaan Harun AL-Rasyid dalam Meningkatkan Motivasi Belajar Mahasiswa adalah, Perpustakaan dijadikan sebagai sumber informasi, perpustakaan sebagai media atau jembatan yang berfungsi mengembangkan ilmu pengetahuan, perpustakaan untuk mencari tugas dan mendalami bahan atau bidang pengetahuan yang diberikan oleh dosen.

\section{REFERENSI}

Abdul Kadir \& Dkk. 2012 Dasar-Dasar Pendidikan, Jakarta: Kencana Premedia Group.

Agustinus Hermino. 2014 Manajemen Kurikulum Berbasis karakter, Bandung: Alfabeta

Anas Sudijono. 2008 Pengantar Statistik Pendidikan, Jakarta: Raja Grafindo Persada

Burhan Bungin. 2010 Metodologi Penelitian Kuantitatif, Jakarta: Media Group

Dadang Sahardan \& Dkk. 2013 Manajemen Pendidikan, Bandung: Alfabeta

Departemen Pendidikan Nasional. 2016 Kamus Besar Bahasa Indonesia Pusat Bahasa, Jakarta: Pustaka Utama

Donni Juni Priansa .2015 Manajemen Peserta Didik dan Model Pembelajaran, Bandung: Alfabeta

Euis Hadis, Nurhayati. 2015 Psikologi Dalam Pendidikan, Bandung: Alfabeta

Hasbullah. 2005 Dasar-Dasar Ilmu Pendidikan, Jakarta: PT Raja Grafindo Persada 
Ibrahim Bafadal. 2014 Pengelolaan Perpustakaan Sekolah, Jakarta: Bumi Aksara

Kompri. 2015 Motivasi Pembelajaran Perspektif Guru dan Siswa, Bandung: Remaja Rosdakarya

M. Ngalim Purwanto. 2014 Psikologi Pendidikan, Bandung: PT Remaja Rosdakarya

M. Sobry Sutikno. 2009 Belajar dan Pembelajaran, Bandung: Prospect

Mohamad Syarif Sumantri. 2015 Strategi Pembelajaran, Jakarta: PT RajaGrafindo Persada

Munir. 2012 Pembelajaran Jarak Jauh Berbasis Teknologi Informasi, Bandung: Alfabeta

Riduwan. 2015 Belajar Mudah Penelitian, Bandung: Alfabeta

Rohmalina Wahab. 2016 Psikologi Belajar, Jakarta: Rajawali Pers

Sardiman, A.M. 2016Interaksi Dan Motivasi Belajar Mengajar, Jakarta: Rajawali Pers

Sitepu. 2014 Pengembangan Sumber Belajar, Jakarta: Rajawali Pers

Sugiyono. 2016Metodologi Penelitian Kuantitatif, Kualitatif, Dan $R \& D$, Bandung: Alfabeta

Sutarno Ns. 2006 Perpustakaan Dan Masyarakat, Jakarta: CV Agung Seto

Sutarno NS. 2006 Manajemen Perpustakaan, Jakarta: CV Agung Seto

Syaiful Bahri Djamarah. 2012 Prestasi Belajar dan Kompetensi Guru, Surabaya: Usaha Nasional

Undang-undang Republik Indonesia Pasal 4 Nomor. 43 Tahun 2007, www.bpkp.go.id Di Akses tanggal 08 Januari 2019 jam 20.13 WIB 